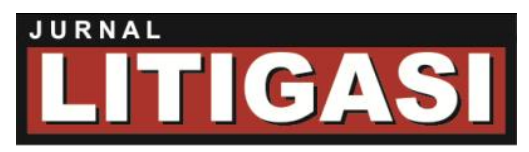

Available online at: http://ejournal.unpas.ac.id/index.php/litigasi

Litigasi, Vol. 16(1), 2015, 2805-2834

DOI: http://dx.doi.org/10.23969/litigasi.v16i1.54

\title{
POLITIK HUKUM PEMBERANTASAN KORUPSI DI ERA REFORMASI; KONSEP DAN REGULASI
}

\author{
Amiziduhu Mendrofa \\ Mahasiswa Program Doktor IImu Hukum Pascasarjana Fakultas Hukum Universitas Andalas Padang, Jl. \\ Limau Manis Kota Padang, Telp: 0751-27404, Hp: 082384196835, E-mail: \\ am mendrova@gmail.com
}

\begin{abstract}
ABSTRAK
Korupsi bukanlah kejahatan baru, tapi kejahatan yang cukup lama. Korupsi tidak hanya terjadi di Indonesia, juga terjadi di negara-negara lain . Bahkan merupakan masalah internasional. Pemberantasan korupsi selalu mendapatkan perhatian lebih dari kejahatan lainnya. Secara umum tindak pidana ini tidak hanya mengakibatkan kerugian negara (keuangan negara), tetapi dapat mengakibatkan dampak yang sangat luas, baik di bidang sosial, ekonomi, keamanan, politik, dan budaya.
\end{abstract}

Kata kunci: Korupsi, Kejahatan, Politik Hukum.

\begin{abstract}
Corruption is not a new crime, but a very quaint old crime. Corruption does not only happen in Indonesia, corruption also occurs in other countries. In fact, this is now regarded as corruption is an international problem. Combating corruption always get more attention than other crimes. In general, these criminal acts are not only result in losses to the state (state finances), but may result in a very broad impact, both in the social, economic, security, political, and cultural.
\end{abstract}

Keywords: Corruption, Crime, Law Politics.

Copyright @ 2015, LITIGASI, p-ISSN: 0853-7100; e-ISSN: 2442-2274 
Available online at: http://ejournal.unpas.ac.id/index.php/litigasi

Litigasi, Vol. 16(1), 2015, 2805-2834

DOI: http://dx.doi.org/10.23969/litigasi.v16i1.54

\section{PENDAHULUAN}

Sepanjang yang bisa diamati, praktik korupsi sudah berada dalam kondisi mengkhawatirkan di Indonesia. Dalam skala internasional, pengukuran terhadap persepsi publik dilakukan oleh berbagai institusi, salah satunya Transparansi International melalui survei corruption perception index (indeks persepsi korupsi, IPK) yang menilai persepsi masyarakat terhadap keberadaan korupsi berdasarkan gabungan beberapa survei dari berbagai lembaga. Survei ini masih menempatkan Indonesia di posisi yang masih rendah kendati ada kecenderungan peningkatan angka. Pada 2011, IPK Indonesia ada pada peringkat ke-100 dari 183 negara dengan skor 3,0 (naik sekitar 0,2 dibandingkan IPK 2010 atau 1,0 sejak 2004).

Hal lain ditunjukkan oleh indeks global corruption barometer (GCB) tahun 2010. Menurut GCB 2010, sebagian responden menyatakan pernah melakukan pembayaran suap. Angkanya mencapai 18 persen. Semakin tinggi indeks di suatu institusi, maka institusi tersebut kian dipersepsikan terkorup. Indeks GCB memberikan skor tertinggi dengan nilai indeks 3,6 untuk lembaga legislatif, disusul lembaga kepolisian dan partai politik dengan indeks 3,5. Yudikatif diganjar indeks 3,3, disusul pejabat eksekutif $(3,2)$.

Begitu parahnya, bentuk penyalahgunaan wewenang itu malah dianggap sebagai sebuah praktik yang lumrah. Melihat kondisi itu, tidak heran kalau dalam tiga tahun terakhir lembaga riset Political and Economic Risk Consultancy (PERC)

Copyright $\odot$ 2015, LITIGASI, p-ISSN: 0853-7100; e-ISSN: 2442-2274 
Available online at: http://ejournal.unpas.ac.id/index.php/litigasi

Litigasi, Vol. 16(1), 2015, 2805-2834

DOI: http://dx.doi.org/10.23969/litigasi.v16i1.54

selalu menempatkan Indonesia sebagai juara korupsi di Asia. Penilaian serupa datang pula dari Transparency International yang selalu menempatkan Indonesia sebagai salah satu negara terkorup di dunia (Saldi Isra, 2009).

Pemberantasan korupsi selalu mendapatkan perhatian yang lebih besar dibandingkan dengan tindak pidana lainnya. Secara umum tindak pidana ini tidak hanya mengakibatkan kerugian negara (keuangan negara), tetapi dapat mengakibatkan dampak yang sangat luas, baik di bidang sosial, ekonomi, keamanan, politik, dan budaya. Jika korupsi menjadi suatu budaya, tindak pidana ini dapat merusak nilai-nilai demokrasi dan moralitas suatu bangsa. Bahkan, menurut Romli Atmasasmita, korupsi selain menyengsarakan rakyat, juga melanggar hak-hak ekonomi dan sosial rakyat (Romli Atmasasmita, 2002).

Menurut Edward Omar Sharif Hiariej, sejak bergulirnya reformasi, isu pemberantasan korupsi selalu menjadi tema sentral dalam penegakan hukum di Indonesia. Korupsi dalam sudut pandang hukum pidana merupakan kejahatan internasional yang memiliki sifat dan karakter sebagai extra ordinary crime (Marwan Effendi, 2013). Paling tidak ada empat sifat dan karakteristik kejahatan korupsi sebagai extra ordinary crime. Pertama, korupsi merupakan kejahatan terorganisasi yang dilakukan secara sistematis. Secara singkat Francis lanni mendefinisikan Kejahatan terorganisasi seperti Mafia di Italia, Yakuza di Jepang, Triad di Cina dan Cartel di Colombia sebagai kejahatan yang dilakukan oleh organisasi non-formal dengan struktur yang tidak rasional untuk menggandakan

Copyright @ 2015 , LITIGASI, p-ISSN: 0853-7100; e-ISSN: 2442-2274 
Available online at: http://ejournal.unpas.ac.id/index.php/litigasi

Litigasi, Vol. 16(1), 2015, 2805-2834

DOI: http://dx.doi.org/10.23969/litigasi.v16i1.54

keuntungan dengan pekerjaan yang seefisien mungkin. Kedua, korupsi biasanya dilakukan dengan modus operandi yang sulit sehingga tidak mudah untuk membuktikannya (Edward Omar Sharif Hiariej, 2012).

Ketiga, korupsi selalu berkaitan dengan kekuasaan. Dalam konteks sifat dan karakteristik korupsi yang ketiga ini, kita mengenal semacam postulat yang dikemukakan oleh Lord Acton bahwa kekuasaan cenderung korup dan kekuasaan yang absolut, korupsinya absolut pula. Keempat, korupsi adalah kejahatan yang berkaitan dengan nasib orang banyak karena keuangan negara yang dapat dirugikan sangat bermanfaat untuk meningkatkan kesejahteraan rakyat. Menurut catatan Bank Dunia per Juni 2007 diperkirakan jumlah aset negara di Indonesia yang telah dikorup sebesar US\$ 15-35 miliar. Sementara merujuk pendapat Danny Leipziger, Wakil Presiden Bank Dunia bidang Pengentasan Kemiskinan dan Manajemen Ekonomi, setiap $\$ 100$ juta uang hasil korupsi yang bisa dikembalikan dapat membangun 240 kilometer jalan, mengimunisasi 4 juta bayi dan memberikan air bersih bagi 250 ribu rumah (Edward Omar Sharif Hiariej, 2012).

Menurut Marwan Effendy, dalam sejarah bangsa Indonesia upaya pemberantasan korupsi dengan cara membentuk suatu badan/tim/komisi pernah dilakukan, seperti (Marwan Effendy, 2005):

(1) Pada permulaan Tahun 1967 dibentuk Tim Pemberantasan Korupsi (TPK). Tahun 1967 s/d 1982 TPK dikendalikan oleh Jaksa Agung, ketika itu diketuai Jaksa Agung Sugih Arto;

(2) Komisi Empat (K4) Januari-Mei 1970 diketuai Wilopo;

Copyright $@$ 2015, LITIGASI, p-ISSN: 0853-7100; e-ISSN: 2442-2274 
(3) Komisi Anti-Korupsi (KAK) Juni-Agustus 1970 beranggotakan Angkatan 66 seperti Akbar Tanjung, dkk.;

(4) Operasi Penertiban (berdasar Inpres No. 9 Tahun 1977) beranggotakan Menpan, Pangkopkamtib, dan Jaksa Agung dibantu pejabat di Daerah dan Kapolri;

(5) Tim Pemberantasan Korupsi (Tahun 1982) diketuai M.A. Mudjono;

(6) Berdasarkan Peraturan Pemerintah Nomor 19 Tahun 2000 dibentuk Tim Gabungan Pemberantasan Tindak Pidana Korupsi (TGTPK) yang diketuai Adi Handoyo;

(7) Komisi Pemeriksa Kekayaan Penyelenggara Negara (KPKPN) yang diketuai Yusuf Syakir;

(8) Lembaga sosial masyarakat yang peduli terhadap korupsi misalnya Indonesian Corruption Watch (ICW), Masyarakat Transparansi Indonesia (MTI), KONSTAN, dan lain sebagainya;

(9) Selain badan tersebut ada juga lembaga atau institusi pengawasan keuangan dan pemerintahan yang dibentuk berdasarkan Undang-Undang Dasar atau undang-undang atau peraturan-peraturan lain yang dikeluarkan pemerintah seperti Badan Pemeriksa Keuangan (BPK), Menko Ekuin Wasbang, BPKP, Inspektur Jenderal, Inspektorat Jenderal, Badan Pengawas Lembaga Nondepartemen, Bawasda Propinsi, dan Bawasda Kabupaten/Kota. 
Available online at: http://ejournal.unpas.ac.id/index.php/litigasi

Litigasi, Vol. 16(1), 2015, 2805-2834

DOI: http://dx.doi.org/10.23969/litigasi.v16i1.54

Berdasarkan uraian di atas, paling tidak dapat dirumuskan tiga masalah yang akan menjadi topik pembahasan dalam tulisan ini, yakni: Apakah era reformasi memiliki pengaruh terhadap gagasan pemberantasan korupsi di Indonesia? Bagaimanakah peran strategis KPK menurut Undang-Undang Republik Indonesia Nomor 30 Tahun 2002 tentang Komisi Pemberantasan Tindak Pidana Korupsi? Bagaimanakah langkah dan strategi pencegahan korupsi yang telah dilakukan oleh KPK selama ini?

\section{PEMBAHASAN}

A. Era Reformasi dan gagasan pemberantasan korupsi

Agenda reformasi hukum itu sendiri setidaknya menyangkut tiga hal, yaitu Pertama, penataan kembali institusi pemerintah dan kenegaraan serta menyeluruh mulai dari Lembaga Tinggi Negara MPR sampai lembaga pemerintahan desa, maupun penataan kembali semua institusi sosial politik dan ekonomi; Kedua, pembaharuan sistem hukum nasional, meliputi: (a) peraturan perundang-undangan mulai naskah konstitusi hingga peraturan desa; (b) struktur kelembagaan hukum; dan (c) peningkatan kualitas aparat dan profesional hukum; Ketiga, pembinaan kesadaran hukum dan budaya hukum, sehingga sikap hormat dan patuh hukum menjadi kehidupan sehari-hari masyarakat maupun penyelenggara negara (Sumali, 2003). UUD 1945 telah mengalami 4 (empat) kali perubahan. Isi UUD 1945 mengalami lebih dari 
Available online at: http://ejournal.unpas.ac.id/index.php/litigasi

Litigasi, Vol. 16(1), 2015, 2805-2834

DOI: http://dx.doi.org/10.23969/litigasi.v16i1.54

300 persen. Sebagai gambaran, sebelum diadakan perubahan, naskah UUD 1945 berisi 71 butir ketentuan atau pasal. Akan tetapi sekarang, setelah mengalami 4 (empat) kali perubahan, ketentuan yang terkandung di dalamnya menjadi 199 butir. Dari perumusan ketentuan yang asli, hanya tersisa 25 butir saja yang sama sekali tidak berubah. Sedangkan selebihnya, yaitu 174 butir, sama sekali merupakan butir-bitir ketentuan baru dalam UUD Negara Republik Indonesia Tahun 1945 (Jimly Asshiddiqie, 2006). Sejak reformasi menggelinding 1998 yang diikuti dengan agenda perubahan atas UUD 1945, kemauan politik (political will) pemerintah untuk melakukan pemberantasan terhadap kejahatan korupsi telah menjadi program prioritas nyata. Era reformasi ini hadir sebagai akibat terjadinya berbagai permasalahan di era orde baru, antara lain tingkat korupsi yang tinggi, krisis ekonomi, krisis kepercayaan serta kondisi stabilitas politik yang buruk. Korupsi pun pada era orde baru menjadi endemik dikalangan birokrat (sipil dan militer). Oleh karena itu, pada era ini pemberantasan korupsi menjadi satu program prioritas penegakan hukum. Hal ini dapat dilihat dengan dikeluarkannya TAP MPR-RI Nomor XI/MPR/1998 tentang Penyelenggaraan Negara yang Bersih dan Bebas Korupsi, Kolusi dan Nepotisme. TAP MPR tersebut merupakan salah satu pedoman dalam rangka menyelamatkan dan menciptakan normalisasi kehidupan nasional sesuai dengan tuntutan reformasi.

Copyright @ $\odot$ 2015, LITIGASI, p-ISSN: 0853-7100; e-ISSN: 2442-2274 
Available online at: http://ejournal.unpas.ac.id/index.php/litigasi

Litigasi, Vol. 16(1), 2015, 2805-2834

DOI: http://dx.doi.org/10.23969/litigasi.v16i1.54

Guna pelaksanaan TAP MPR tersebut, pemerintah dengan persetujuan DPR RI mengundangkan Undang-Undang Nomor 28 Tahun 1999 tentang Penyelenggaraan Negara yang Bersih dan Bebas dari Korupsi, Kolusi dan Nepotisme pada tanggal 19 Mei Tahun 1999. Tetapi menurut Andi Hamzah rumusan deliknya tidak ada sehingga sulit Jaksa membuat surat dakwaan. Ada sanksi, tetapi tidak ada rumusan delik (defenisi delik). Tidak ada defenisi delik dalam rumusan, bagaimana membuktikan seseorang telah melakukan nepotisme (Andi Hamzah, 2012).

Selain itu, Undang-Undang Nomor 3 Tahun 1971 tentang Pemberantasan Tindak Pidana Korupsi dinilai memiliki kelemahan-kelemahan dan dapat menghambat reformasi. Menurut Romli Atmasasmita UndangUndang Nomor 3 Tahun 1971 tentang Pemberantasan Tidak Pidana Korupsi terdapat kelemahan-kelemahan antara lain: a. Kelemahan dalam hukum material terletak pada ketentuan mengenai rumusan delik yang bersifat materiel tidak dirumuskan secara formil; $b$. Unsur kerugian keuangan negara atau perekonomian negara merupakan salah satu unsur mutlak uang harus dapat dibuktikan oleh Jaksa Penuntut Umum; c. Peraturan Mahkamah Agung yang menegaskan antara lain berkas tindak pidana korupsi tidak terbukti jika kepentingan umum terlayani, terdakwa tidak memperoleh keuntungan dan negara tidak dirugikan; d. Dalam rumusan delik dalam perihal sanksi pidana yang telah menetapkan maksimal umum dan tidak ada batasan minimal khusus,

Copyright @ 2015 , LITIGASI, p-ISSN: 0853-7100; e-ISSN: 2442-2274 
Available online at: http://ejournal.unpas.ac.id/index.php/litigasi

Litigasi, Vol. 16(1), 2015, 2805-2834

DOI: http://dx.doi.org/10.23969/litigasi.v16i1.54

sehingga Jaksa Penuntut Umum maupun Hakim dapat bergerak leluasa dalam batasan minimal umum (satu hari) dan maksimal umum yang ditetapkan dalam UUTPK 1971 (Romli Atamasasmita, 1999).

Oleh karena itu pada tanggal 16 Agustus 1999 diundangkanlah Undang-Undang Nomor 31 Tahun 1999 tentang Pemberantasan Tindak Pidana Korupsi dan menyatakan Undang-Undang No. 3 Tahun 1971 tidak berlaku lagi.

Delik dalam Undang-Undang Nomor 31 Tahun 1999 dapat dikelompokkan sebagai berikut; Pertama, Kelompok delik yang dapat merugikan keuangan negara atau perekonomian negara, (sebagaimana diatur dalam Pasal 2 ayat (1) dan Pasal 3 Undang-Undang Nomor 31 Tahun 1999 jo. Undang-Undang Nomor 20 Tahun 2001 tentang Pemberantasan Tindak Pidana Korupsi). Kedua, Kelompok delik penyuapan, baik aktif (yang menyuap) maupun pasif (yang disuap) serta gratifikasi (sebagaimana diatur dalam Pasal 5 ayat (1) dan ayat (2), Pasal 6 ayat (1) dan ayat (2), Pasal 11, Pasal 12 huruf a, b, c, dan d, serta Pasal 12B ayat (1) dan ayat (2) UndangUndang Nomor 31 Tahun 1999 jo. Undang-Undang Nomor 20 Tahun 2001 tentang Pemberantasan Tindak Pidana Korupsi). Ketiga, Kelompok delik penggelapan (sebagaimana diatur dalam Pasal 8, Pasal 10 huruf a UndangUndang Nomor 31 Tahun 1999 jo. Undang-Undang Nomor 20 Tahun 2001 tentang Pemberantasan Tindak Pidana Korupsi). Keempat, Kelompok

Copyright @ 2015 , LITIGASI, p-ISSN: 0853-7100; e-ISSN: 2442-2274 
Available online at: http://ejournal.unpas.ac.id/index.php/litigasi

Litigasi, Vol. 16(1), 2015, 2805-2834

DOI: http://dx.doi.org/10.23969/litigasi.v16i1.54

delik pemerasan dalam jabatan (knevelarij, extortion) (sebagaimana diatur dalam Pasal 12 huruf e dan huruf f Undang-Undang Nomor 31 Tahun 1999 jo. Undang-Undang Nomor 20 Tahun 2001 tentang Pemberantasan Tindak Pidana Korupsi). Kelima, Kelompok delik pemalsuan (sebagaimana diatur dalam Pasal 9 Undang-Undang Nomor 31 Tahun 1999 jo. Undang-Undang Nomor 20 Tahun 2001 tentang Pemberantasan Tidak Pidana Korupsi). Keenam, Kelompok delik yang berkaitan dengan pemborongan, leveransir dan rekanan (sebagaimana diatur dalam Pasal 7 ayat (1) dan ayat (2), Pasal 12 huruf g dan huruf i Undang-Undang Nomor 31 Tahun 1999 jo. UndangUndang Nomor 20 Tahun 2001 tentang Pemberantasan Tindak Pidana Korupsi). Dari 6 (enam) kelompok delik di atas, hanya 1 (satu) kelompok saja yang memuat unsur merugikan negara diatur di dalam 2 pasal yaitu Pasal 2 dan 3, sedangkan 5 kelompok lainnya yang terdiri dari 28 pasal terkait dengan perilaku menyimpang dari penyelenggara negara atau pegawai negeri dan pihak swasta.

Bila dibaca konsideran "menimbang" Undang-Undang No. 31 Tahun 1999, setidaknya terdapat 3 (tiga) alasan pembentukan undang-undang ini, yakni;

(1) bahwa tindak pidana korupsi sangat merugikan keuangan negara atau perekonomian negara dan menghambat pembangunan nasional, sehingga harus diberantas dalam rangka mewujudkan masyarakat adil dan makmur berdasarkan Pancasila dan Undang-Undang Dasar 1945;

Copyright @ 2015, LITIGASI, p-ISSN: 0853-7100; e-ISSN: 2442-2274 
Available online at: http://ejournal.unpas.ac.id/index.php/litigasi

Litigasi, Vol. 16(1), 2015, 2805-2834

DOI: http://dx.doi.org/10.23969/litigasi.v16i1.54

(2) bahwa akibat tindak pidana korupsi yang terjadi selama ini selain merugikan keuangan negara atau perekonomian negara, juga menghambat pertumbuhan dan kelangsungan pembangunan nasional yang menuntut efisiensi tinggi;

(3) bahwa Undang-undang Nomor 3 Tahun 1971 tentang Pemberantasan Tindak Pidana Korupsi sudah tidak sesuai lagi dengan perkembangan kebutuhan hukum dalam masyarakat, karena itu perlu diganti dengan Undang-undang Pemberantasan Tindak Pidana Korupsi yang baru sehingga diharapkan lebih efektif dalam mencegah dan memberantas tindak pidana korupsi;

Berdasarkan rumusan konsideran "menimbang” Undang-Undang No. 31 Tahun 1999 di atas, tampak jelas bahwa kehadiran undang-undang pemberantasan tindak pidana korupsi yang baru lebih didasari kepada ketidakmampuan Undang-Undang No. 3 Tahun 1971 sebagai payung hukum dalam pemberantasan tindak pidana korupsi di Indonesia (Yopie Morya Immanuel Patiro, 2012).

B. Peran Strategis Komisi Pemberantasan Korupsi

Sesuai dengan ketentuan Pasal 43 Undang-Undang No. 31 Tahun 1999 sebagaimana telah diubah dengan Undang-undang Nomor 20 Tahun 2001 tentang Perubahan atas Undang-Undang Nomor 31 Tahun 1999 
Available online at: http://ejournal.unpas.ac.id/index.php/litigasi

Litigasi, Vol. 16(1), 2015, 2805-2834

DOI: http://dx.doi.org/10.23969/litigasi.v16i1.54

tentang Pemberantasan Tindak Pidana Korupsi, perlu dibentuk Komisi Pemberantasan Tindak Pidana Korupsi yang independen dengan tugas dan wewenang melakukan pemberantasan tindak pidana korupsi. Selain dari perintah Pasal 43 Undang-Undang Nomor 31 Tahun 1999 tentang Pemberantasan Tindak Pidana Korupsi sebagaimana telah diubah dengan Undang-Undang Nomor 20 Tahun 2001 tentang Perubahan atas UndangUndang Nomor 31 Tahun 1999 tentang Pemberantasan Tindak Pidana Korupsi, pembentukan Komisi Pemberantasan Korupsi (KPK) yang dapat dibaca pada konsideran "menimbang" Undang-undang Nomor 30 Tahun 2002 tentang Komisi Pemberantasan Korupsi adalah juga dalam rangka mewujudkan masyarakat yang adil, makmur, dan sejahtera berdasarkan Pancasila dan Undang-Undang Dasar Negara Republik Indonesia Tahun 1945, pemberantasan tindak pidana korupsi yang terjadi sampai sekarang belum dapat dilaksanakan secara optimal. Oleh karena itu pemberantasan tindak pidana korupsi perlu ditingkatkan secara profesional, intensif, dan berkesinambungan karena korupsi telah merugikan keuangan negara, perekonomian negara, dan menghambat pembangunan nasional, serta karena lembaga pemerintah yang menangani perkara tindak pidana korupsi belum berfungsi secara efektif dan efisien dalam memberantas tindak pidana korupsi.

Pada tanggal 27 Desember 2002 diundangkanlah Undang-Undang Republik Indonesia Nomor 30 Tahun 2002 tentang Komisi Pemberantasan Tindak Pidana Korupsi. Undang-Undang ini juga mengatur kewenangan

Copyright $\odot$ 2015, LITIGASI, p-ISSN: 0853-7100; e-ISSN: 2442-2274 
Available online at: http://ejournal.unpas.ac.id/index.php/litigasi

Litigasi, Vol. 16(1), 2015, 2805-2834

DOI: http://dx.doi.org/10.23969/litigasi.v16i1.54

melakukan koordinasi dan supervisi termasuk melakukan penyelidikan, penyidikan, dan penuntutan tindak pidana korupsi. Adanya penggantian norma hukum pemberantasan korupsi di atas menunjukkan arah kebijakan yang sama, yakni melakukan perbaikan norma hukum agar upaya pemberantasan korupsi berjalan dengan baik (Hibnu Nugroho, 2012). Di samping itu Indonesia juga telah meratifikasi Konvensi PBB Anti Korupsi Tahun 2003 dengan Undang-Undang Nomor 7 Tahun 2006 tentang Pengesahan Konvensi Anti Korupsi (United Nations Convention Against Corruption, 2003).

KPK dibentuk dengan misi utama melakukan penegakan hukum, yakni dalam hal pemberantasan korupsi. Dibentuknya lembaga ini dikarenakan adanya pemikiran bahwa lembaga penegak hukum konvensional, seperti Kejaksaan dan Kepolisian, dianggap belum mampu memberantas korupsi (Hibnu Nugroho, 2012).

Oleh karena itu perlu dibentuk lembaga khusus yang mempunyai kewenangan luas dan independen serta bebas dari kekuasaan mana pun (Hibnu Nugroho, 2012). Selain itu, dengan semakin canggihnya cara orang melakukan korupsi, badan penegak hukum konvensional semakin tidak mampu mengungkapkan dan membawa kasus korupsi besar ke pengadilan.

Copyright @ C 2015, LITIGASI, p-ISSN: 0853-7100; e-ISSN: 2442-2274 
Available online at: http://ejournal.unpas.ac.id/index.php/litigasi

Litigasi, Vol. 16(1), 2015, 2805-2834

DOI: http://dx.doi.org/10.23969/litigasi.v16i1.54

Pentingnya pembentukan lembaga khusus pemberantasan tindak pidana

korupsi (spcialized anti-corruption agencies) juga dipersyaratkan dalam ketentuan internasional yakni Pasal 6 Konvensi Perserikatan Bangsa-Bangsa Menentang Korupsi 2003 yang berbunyi sebagai berikut :

Article 6 (1)

Preventive Anti-Corruption Body or Bodies

"Each State Party shall, in Accordance with the fundamental principles of its legal system, ensure the existence of body or bodies, as appropriate, that prevent corruption by such means as: "(Setiap negara peserta wajib, sesuai dengan prinsip-prinsip dasar dan sistem hukumnya, memastikan keberadaan suatu badan atau badan-badan, sejauh diperlukan, untuk mencegah korupsi dengan cara-cara seperti:) (Mahmuddin Muslim, 2004),

Lahirnya konvensi $P B B$ tentang korupsi, merupakan babak baru pemberantasan korupsi dimulai. Korupsi tidak lagi dianggap sebagai masalah nasional semata akan tetap telah berkembang menjadi transnational Organized crime, kejahatan terorganisir yang mencakup banyak dan antar negara. Konvensi ini diterima baik oleh Sidang ke-58 Majelis Umum PBB dan dituangkan dalam resolusi No. 58/4 tanggal 31 Oktober 2003 (Syaiful Ahmad Dinar, 2012).

KPK dan berbagai peraturan perundang-undangan yang lahir dengan maksud untuk memberantas korupsi telah diterbitkan, namun praktik korupsi masih terus berulang dan semakin kompleks dalam realisasinya. Bahkan hal ini

Copyright @ C 2015, LITIGASI, p-ISSN: 0853-7100; e-ISSN: 2442-2274 
Available online at: http://ejournal.unpas.ac.id/index.php/litigasi

Litigasi, Vol. 16(1), 2015, 2805-2834

DOI: http://dx.doi.org/10.23969/litigasi.v16i1.54

diperparah lagi dengan korupsi yang dilakukan oleh aparat penegak hukum yang seharusnya bertugas memberantas korupsi dan menegakkan peraturan yang berlaku.

Korupsi yang terjadi di lingkungan peradilan mengakibatkan lembaga peradilan menjadi tidak independen dan tidak imparsial, sehingga timbul ketidakpastian hukum, ketidakmandirian lembaga peradilan dan institusi hukum (polisi, jaksa penuntut umum, advokat dan hakim) kemudian selanjutnya inilah yang disebut sebagai judicial corruption.

Menurut Pasal 2 dan 3 Undang-Undang No. 30 Tahun 2002, KPK adalah lembaga negara yang melaksanakan tugas dan wewenangnya bersifat independen dan bebas dari pengaruh kekuasaan manapun. Pemberantasan tindak pidana korupsi berdasarkan Pasal 1 angka 3 Undang-Undang No. 30 Tahun 2002 adalah serangkaian tindakan untuk mencegah dan memberantas tindak pidana korupsi melalui upaya koordinasi, supervisi, monitor penyelidikan, penyidikan, penuntutan, dan pemeriksaan di sidang pengadilan, dengan peran serta masyarakat berdasarkan peraturan perundang-undangan yang berlaku (Ermansyah Djaja, 2010).

Tindak pidana korupsi di Indonesia tetap saja terus merasuk ke dalam sendi-sendi kehidupan masyarakat, setidaknya hal itu dapat dirasakan di kehidupan sehari-hari tanpa terkecuali di bidang perbankan. Lembaga perbankan dalam perekonomian Indonesia menduduki posisi yang strategis. Perekonomian nasional dan internasional berkembang dengan sangat cepat,

Copyright $\odot$ 2015, LITIGASI, p-ISSN: 0853-7100; e-ISSN: 2442-2274 
Available online at: http://ejournal.unpas.ac.id/index.php/litigasi

Litigasi, Vol. 16(1), 2015, 2805-2834

DOI: http://dx.doi.org/10.23969/litigasi.v16i1.54

kompetitif dan terintegrasi, sehingga memunculkan tantangan yang semakin kompleks dan menuntut sistem yang semakin maju. Fungsi bank tidak hanya sekedar sebagai lembaga yang hanya menghimpun dana dari masyarakat dan menyalurkannya kembali dalam berbagai fasilitas perbankan (financial intermediary), namun telah jauh berkembang menjadi pilar bagi pertumbuhan ekonomi, sosial, bahkan politik (Marwan Effendy, 2010).

Itikad pemberantasan korupsi terdorong ke seluruh Indonesia. Hal itu ditunjukkan dengan semakin meningkatnya keuangan/aset negara yang terselamatkan pada setiap tahunnya dalam pencegahan dan penuntasan kasus korupsi. Sejumlah institusi pelaksana dan pendukung pemberantasan korupsi pun terbentuk, antara lain selain KPK, sekarang telah juga dibentuk Pusat Pelaporan dan Analisis Transaksi Keuangan, serta Lembaga Perlindungan Saksi dan Korban.

Presiden juga telah menerbitkan sejumlah instruksi dan arahan untuk pencegahan dan pemberantasan korupsi, misalnya Instruksi Presiden (Inpres) 5 Tahun 2004 tentang Percepatan Pemberantasan Korupsi di Indonesia. Melalui Inpres ini, Presiden mengamanati berbagai langkah strategis, diantaranya berupa Rencana Aksi Nasional Pemberantasan dan Pemberantasan Korupsi (RAN-PPK) 2004-2009. Dokumen yang dimaklumatkan sebagai acuan bagi para pihak di pemerintahan Pusat dan Daerah dalam memberantas korupsi ini menekankan upaya-upaya pencegahan dan penindakan, selain juga sebagai pedoman bagi pelaksanaan monitoring dan evaluasi.

Copyright @ C 2015, LITIGASI, p-ISSN: 0853-7100; e-ISSN: 2442-2274 
Available online at: http://ejournal.unpas.ac.id/index.php/litigasi

Litigasi, Vol. 16(1), 2015, 2805-2834

DOI: http://dx.doi.org/10.23969/litigasi.v16i1.54

Mei 2011, Presiden memaklumatkan Inpres Nomor 9 Tahun 2011 tentang Rencana Aksi Percepatan Pemberantasan Korupsi Tahun 2011, yang diteruskan dengan Inpres Nomor 17 Tahun 2011 tentang Aksi Nasional Percepatan Pemberantasan Korupsi Tahun 2012 pada Desember 2011. Melalui Inpres Nomor 17 Tahun 2011, Presiden menginstruksikan pelaksanaan berbagai rencana aksi yang terinci dengan fokus utama pencegahan korupsi pada lembaga penegak hukum. Aksinya berupa peningkatan akuntabilitas, keterbukaan informasi, kapasitas dan pembinaan sumber daya manusia, serta koordinasi antar lembaga. Inpres No. 9 Tahun 2011 dan Inpres No. 17 Tahun 2011 diharapkan menjadi bagian pertama dan kedua dari rangkaian RAN-PPK yang akan diselenggarakan tahunan. RAN PPK ini dapat dianggap penting dalam rangka memperkuat kelembagaan KPK.

Kewenangan KPK tidak hanya "melakukan penyelidikan, penyidikan, dan penuntutan terhadap tindak pidana korupsi” tetapi juga memiliki tugas lainnya yang tidak kalah penting maka kemampuan KPK dalam menindaklanjuti kasus korupsi hanya merupakan salah satu tolok ukur yang dapat digunakan untuk menilai kinerja KPK.

Pasal 6 Undang-Undang Nomor 30 Tahun 2002, yakni Komisi Pemberantasan Korupsi mempunyai tugas: a. koordinasi; b. supervisi; c. melakukan penyelidikan, penyidikan, dan penuntutan terhadap tindak pidana korupsi; d. melakukan tindakan-tindakan pencegahan; dan e. melakukan monitor terhadap penyelenggaraan pemerintahan negara.

Copyright @ $\odot$ 2015, LITIGASI, p-ISSN: 0853-7100; e-ISSN: 2442-2274 
Available online at: http://ejournal.unpas.ac.id/index.php/litigasi

Litigasi, Vol. 16(1), 2015, 2805-2834

DOI: http://dx.doi.org/10.23969/litigasi.v16i1.54

Tarik menarik ini sangat alot sehinga terkesan ada pihak yang ingin melemahkan fungsi Komisi Pembarantasan Korupsi dan Pengadilan Tindak Pidana Korupsi. Namun demikian atas kesadaran bersama antara Pemerintah dan Dewan Perwakilan Rakyat lahirlah Pengadilan Tindak Pidana Korupsi di Indonesia. Komisi Pemberantasan Korupsi (KPK) dan Pengadilan Tindak Pidana Korupsi (Pengadilan TIPIKOR) merupakan dua sejoli gabungan dari organ eksekutif dan yudikatif yang menjadi tumpuan seluruh masyarakat Indonesia untuk menanggulangi dan menekan tindak pidana korupsi, karena sebagaimana telah diuraikan di muka, organ-organ eksekutif dalam bidang penegakan hukum yaitu Kepolisian dan Kejaksaan belum berfungsi secara efektif dan efisien.

Beberapa hal penting yang perlu diketahui tentang kedudukan, tugas dan wewenang Komisi Pemberantasan Korupsi adalah:

1. KPK adalah lembaga negara yang dalam menjalankan tugas dan wewenangnya bersifat independen dan bebas dari pengaruh kekuasaan apapun. KPK dibentuk dengan tujuan meningkatkan daya guna dan hasil guna terhadap upaya pemberantasan tindak pidana korupsi.

2. Dalam menjalankan tugasnya, KPK berasaskan pada kepastian hukum, keterbukaan, akuntabilitas, kepentingan umum dan proporsionalitas.

Copyright @ $\odot$ 2015, LITIGASI, p-ISSN: 0853-7100; e-ISSN: 2442-2274 
Available online at: http://ejournal.unpas.ac.id/index.php/litigasi

Litigasi, Vol. 16(1), 2015, 2805-2834

DOI: http://dx.doi.org/10.23969/litigasi.v16i1.54

\section{Pencegahan Korupsi oleh KPK}

KPK dalam melakukan pemberantasan terhadap korupsi memakai dua cara, yaitu menindak/ represif dan mencegah/ preventif (Deni Setiawan, 2008). Pemberantasan korupsi yang hanya sekedar bersifat menindak/represif hasilnya tidak akan sanggup mengenyahkan korupsi sampai ke akar-akarnya. Dibutuhkan juga langkah preventif yang berfungsi untuk mencegah tumbuhnya kembali penyakit korupsi di masa mendatang. Oleh karena itu selain menjalankan langkah represif, KPK juga menjalankan langkah preventif (mencegah). Termasuk dalam langkah mencegah (preventif) antara lain; pendaftaran dan pemeriksaan LHKPN, gratifikasi, pendidikan dan pelayanan masyarakat, penelitian dan pengembangan monitoring dan pengembangan jaringan kerjasama (Deni Setiawan, 2008).

Langkah pencegahan atas tindak pidana korupsi adalah amat langsung dari Undang-Undang Nomor 30 Tahun 2002. Pasal 6 mengatur bahwa; Komisi Pemberatasan Korupsi mempunyai tugas; d. melakukan tindakantindakan pencegahan tindak pidana korupsi".

Konsep pencegahan kejahatan (crime prevention) menurut The National Crime Prevention Institut; "is defines crime prevention as the anticipation, recognition and appraisal of a crime risk and the initiation of some action to remove or reduce it" (O 'Block L. Robert, 1981). 
Available online at: http://ejournal.unpas.ac.id/index.php/litigasi

Litigasi, Vol. 16(1), 2015, 2805-2834

DOI: http://dx.doi.org/10.23969/litigasi.v16i1.54

Jadi, pencegahan kejahatan adalah proses antisipasi, identifikasi dan estimasi resiko akan terjadinya kejahatan dan melakukan inisiasi atau sejumlah tindakan untuk menghilangkan atau mengurangi kejatahan. Tindakan preventif adalah tindakan pencegahan yaitu langkah-langkah yang diambil untuk tidak terjadinya korupsi. Ada pepatah yang mengatakan "prevention is better than cure”, mencegah lebih baik daripada mengobati. Tindakan preventif ini perlu dilakukan di semua instansi pemerintah apalagi instansi pemerintah yang rawan terjadinya tindak pidana korupsi. Perlu diciptakan suatu sistem pengawasan yang ketat oleh lembaga-lembaga pengawas baik pengawasan parlemen yang dilakukan oleh Dewan Perwakilan Rakyat dan Dewan Perwakilan Rakyat Daerah, pengawasan internal yang dilakukan oleh Inspektorat Jenderal (pengawasan melekat) maupun pengawasan yuridis yang dilakukan oleh Kepolisian dan Kejaksaan.

Tindakan represif atau tindakan penegakan hukum adalah tindakan yang dilakukan terhadap orang atau pelaku yang telah melakukan tindak pidana korupsi. Tindakan hukum ini tidak boleh pandang bulu atau tebang pilih. Siapapun yang disangka melakukan tindak pidana korupsi harus diproses di pengadilan. Bahkan di Indonesia sudah ada semacam "preseden" bahwa seorang besan dari Presidenpun dapat dituntut dan dijatuhi pidana karena melakukan tindak pidana korupsi. Hal yang juga dapat dipikirkan untuk menimbulkan efek jera terhadap pelaku tindak pidana korupsi adalah jenis pidana yang dijatuhkan. Maraknya tindak pidana korupsi di Indonesia 
Available online at: http://ejournal.unpas.ac.id/index.php/litigasi

Litigasi, Vol. 16(1), 2015, 2805-2834

DOI: http://dx.doi.org/10.23969/litigasi.v16i1.54

kemungkinan disebabkan karena pidana yang dijatuhkan tidak mempunyai efek jera, misalnya belum ada seorang koruptor yang dijatuhi pidana mati seperti di Cina. Paling tinggi dua puluh tahun dan bahkan belum ada yang dipidana seumur hidup. Pengadilan Beijing menjatuhkan hukuman mati terhadap mantan menteri kereta api Cina Liu Zhijun atas tuduhan penyuapan dan penyalahgunaan wewenang dalam skandal korupsi (http://www.republika.co.id, 2013).

Di dalam kelembagaan KPK dibentuk Deputi Bidang Pencegahan yang mempunyai tugas menyiapkan rumusan kebijakan dan melaksanakan kebijakan di Bidang Pencegahan Tindak Pidana Korupsi. Deputi Bidang Pencegahan menyelenggarakan fungsi (http://www.kpk.go.id, 2013):

(1) Perumusan kebijakan untuk sub bidang Pendaftaran dan Penyelidikan Laporan Harta Kekayaan Penyelenggaran Negara (PP LHKPN), Gratifikasi, Pendidikan dan Pelayanan Masyarakat serta Penelitian dan Pengembangan;

(2) Pelaksanaan pencegahan korupsi melalui pendataan, pendaftaran dan pemeriksaan LHKPN;

(3) Pelaksanaan pencegahan korupsi melalui penerimaan pelaporan dan penanganan gratifikasi yang diterima oleh Pegawai Negeri atau Penyelenggara Negara;

(4) Pelaksanaan pencegahan korupsi melalui pendidikan anti korupsi, sosialisasi pemberantasan tindak pidana korupsi dan kampanye antikorupsi;

Copyright @ 2015, LITIGASI, p-ISSN: 0853-7100; e-ISSN: 2442-2274 
Available online at: http://ejournal.unpas.ac.id/index.php/litigasi

Litigasi, Vol. 16(1), 2015, 2805-2834

DOI: http://dx.doi.org/10.23969/litigasi.v16i1.54

(5) Pelaksanaan pencegahan korupsi melalui penelitian, pengkajian dan pengembangan pemberantasan korupsi;

(6) Koordinasi dan supervisi pencegahan tindak pidana korupsi kepada instansi terkait dan instansi yang dalam melaksanakan pelayanan publik;

(7) Pelaksanaan kegiatan kesekretariatan dan pembinaan sumber daya di lingkungan Deputi Bidang Pencegahan.

(8) Koordinasi, sinkronisasi, pemantauan, evaluasi dan pelaksanaan hubungan kerja pada sub bidang Pendaftaran dan Penyelidikan Laporan Harta Kekayaan Penyelenggaran Negara (PP LHKPN), Gratifikasi, Pendidikan dan Pelayanan Masyarakat serta Penelitian dan Pengembangan;

(9) Pelaksanaan tugas lain yang diberikan oleh Pimpinan sesuai dengan bidangnya.

Menyangkut kompisis Sumber Daya Manusia (SDM) menurut unit organisasi KPK dapat dilihat pada tabel berikut ini;

Copyright $\odot$ 2015, LITIGASI, p-ISSN: 0853-7100; e-ISSN: 2442-2274 
Available online at: http://ejournal.unpas.ac.id/index.php/litigasi

Litigasi, Vol. 16(1), 2015, 2805-2834

DOI: http://dx.doi.org/10.23969/litigasi.v16i1.54

Tabel Komposisi SDM Menurut Unit Organisasi

\begin{tabular}{|l|l|l|}
\hline No & Unit Organisasi & Jumlah \\
\hline 1 & Pimpinan & 5 \\
\hline 2 & Penasehat & 2 \\
\hline 3 & Pencegahan & 134 \\
\hline 4 & Penindakan & 190 \\
\hline 5 & Informasi dan Data (INDA) & 127 \\
\hline 6 & $\begin{array}{l}\text { Pengawasan Internal dan Pengaduan } \\
\text { Masyarakat (PIPM) }\end{array}$ & 73 \\
\hline 7 & Sekretariat Jenderal (Setjen) & 143 \\
\hline & Total & 674 \\
\hline
\end{tabular}

Tabel: 1

Laporan Tahunan (LAPTAH) KPK Tahun 2012.

Melaksanakan tugas pencegahan tindak pidana korupsi, KPK berwewenang (Ermansyah Djaja, 2010):

(1) Melakukan pendaftaran dan memeriksaan terhadap laporan harta kekayaan penyelenggaraan negara;

(2) Menerima laporan dan menetapkan status gratifikasi;

(3) Menyelenggarakan program pendidikan anti korupsi pada setiap jenjang pendidikan;

(4) Merancang dan mendorong terlaksananya program nasionalisasi pemberantasan tindak pidana korupsi;

(5) Melakukan kampenye antikorupsi kepada masyarakat umum;

Copyright @ C 2015, LITIGASI, p-ISSN: 0853-7100; e-ISSN: 2442-2274 
Available online at: http://ejournal.unpas.ac.id/index.php/litigasi

Litigasi, Vol. 16(1), 2015, 2805-2834

DOI: http://dx.doi.org/10.23969/litigasi.v16i1.54

(6) Melakukan kerja sama bilateral atau multilateral dalam pemberantasan tindak pidana korupsi.

Menurut Syaiful Ahmad Dinar, bahwa dalam implimentasi kewenangan dan fungsi Komisi Pemberantasan Korupsi dibidang preventif, KPK telah dilaksanakan pencegahan antara lain (Syaiful Ahmad Dinar, 2012):

(1) KPK melakukan upaya untuk menciptakan semangat anti korupsi di masyarakat.

(2) KPK telah berupaya melakukan sosialisasi kepada masyarakat. Bahwa peran serta masyarakat yang dijamin oleh hukum, bersama KPK ikut serta melakukan pengawasan, pencematan, telaah kritis terhadap wilayah sektor publik, keuangan negara, penegakan hukum, dan lembaga pengawasan menjadi sektor-sektor yang mendapat perhatian lebih. Peningkatan peran serta masyarakat terkait pengawasan, karena pada sektor tersebut "tindak pidana korupsi" sering terjadi. KPK memberikan pemahaman atau pelatihan kepada khalayak untuk membangkitkan kesadaran akan bahaya korupsi.

(3) KPK telah berupaya mentargetkan untuk bisa terus menyuarakan pentingnya reformasi dibidang politik, ekonomi, hukum, sosial, administrasi, adan birokrasi. Karena itu penting untuk terus mengingatkan masyarakat bahwa reformasi di segala bidang memerlukan waktu bukan sesaat. Target yang paling mudah dikontrol bagi kesertaan masyarakat, 
Available online at: http://ejournal.unpas.ac.id/index.php/litigasi

Litigasi, Vol. 16(1), 2015, 2805-2834

DOI: http://dx.doi.org/10.23969/litigasi.v16i1.54

yakni mendorong pemikiran kritis guna mengkoreksi penyelenggaraan ketatanegaraan dan pemerintah dilakukan secara teransparan, akuntabel, dan partisipatif agar memudahkan pengawasan oleh semua lapisan masyarakat. Upaya tersebut menjadi bagian dari sistem pemberantasan tindak pidana korupsi.

(4) KPK melakukan upaya konsolidasi kerja sama dengan berbagai institusi atau lembaga lintas sektoral guna percepatan proses perwujudan pemberantasan tindak pidana korupsi. Upaya yang dilakukan antara lain; kerja sama KPK, Kepolisian, dan Kejaksaan yang dilakukan secara proporsional dan profesional.

(5) Untuk meningkatkan kesadaran pelaporan gratifikasi, KPK melakukan sosialisasi tentang gratifikasi kepada lembaga negara, kementerian/departeman, pemda, BUMN, perusahaan swasta, dan LSM secara diseminasi form gratifikasi dan perangkat lainnya kepada pemerintah propinsi dan kota/kabupaten.

Berdasarkan Laporan Tahunan KPK Tahun 2012, terurai bahwa Pilkada DKI Jakarta merupakan pilot project pelaksanaan program pencegahan korupsi melalui pengawasan penyelenggaraan pemilu. Kegiatan ini dimulai dari proses pencalonan sampai calon terpilih. Sebelum proses pencalonan, KPK melaksanakan diskusi dengan KPUD DKI Jakarta untuk meminta masukan dari KPUD, terkait langkah-langkah apa saja yang bisa dilakukan KPK untuk ikut

Copyright @ C 2015, LITIGASI, p-ISSN: 0853-7100; e-ISSN: 2442-2274 
Available online at: http://ejournal.unpas.ac.id/index.php/litigasi

Litigasi, Vol. 16(1), 2015, 2805-2834

DOI: http://dx.doi.org/10.23969/litigasi.v16i1.54

membantu KPUD DKI dalam proses demokrasi itu. Termasuk rangkaian pencegahan korupsi dalam proses pilkada, KPK juga melakukan verifikasi dan klarifikasi laporan harta kekayaan para kandidat. Dalam hal ini, KPK antara lain mendatangi langsung kediaman para calon gubernur dan calon wakil gubernur guna melakukan cek silang terhadap LHKPN yang sudah dilaporkan (Komisi Pemberantasan Korupsi, 2012). 
Available online at: http://ejournal.unpas.ac.id/index.php/litigasi

Litigasi, Vol. 16(1), 2015, 2805-2834

DOI: http://dx.doi.org/10.23969/litigasi.v16i1.54

\section{SIMPULAN DAN SARAN}

\section{A. Simpulan}

1. Era reformasi memiliki pengaruh terhadap gagasan pemberantasan korupsi di Indonesia. Sejak reformasi menggelinding 1998, yang diikuti dengan agenda perubahan atas UUD 1945, kemauan politik (political will) pemerintah untuk melakukan pemberantasan terhadap kejahatan korupsi telah menjadi program prioritas nyata. Era reformasi ini hadir sebagai akibat terjadinya berbagai permasalahan di era orde baru, antara lain tingkat korupsi yang tinggi, krisis ekonomi, krisis kepercayaan serta kondisi stabilitas politik yang buruk.

2. KPK dibentuk berdasarkan Undang-Undang Nomor 30 Tahun 2002 tentang Komisi Pemberantasan Tindak Pidana Korupsi dengan misi utama melakukan penegakan hukum, yakni dalam hal pemberantasan korupsi. Dibentuknya lembaga ini dikarenakan adanya pemikiran bahwa lembaga penegak hukum konvensional, seperti Kejaksaan dan Kepolisian, dianggap belum mampu memberantas korupsi. Oleh karena itu perlu dibentuk lembaga khusus yang mempunyai kewenangan luas dan independen serta bebas dari kekuasaan mana pun. Selain itu, dengan semakin canggihnya cara orang melakukan korupsi, badan penegak hukum konvensional semakin tidak mampu mengungkapkan dan membawa kasus korupsi besar ke pengadilan. 
Available online at: http://ejournal.unpas.ac.id/index.php/litigasi

Litigasi, Vol. 16(1), 2015, 2805-2834

DOI: http://dx.doi.org/10.23969/litigasi.v16i1.54

3. Langkah dan strategi pencegahan korupsi yang telah dilakukan oleh KPK Langkah pencegahan atas tindak pidana korupsi adalah amanat langsung dari Undang-undang Nomor 30 Tahun 2002. Pasal 6 mengatur bahwa; Komisi Pemberatasan Korupsi mempunyai tugas; d. melakukan tindakantindakan pencegahan tindak pidana korupsi". Di dalam kelembagaan KPK dibentuk Deputi Bidang Pencegahan yang mempunyai tugas menyiapkan rumusan kebijakan dan melaksanakan kebijakan di Bidang Pencegahan Tindak Pidana Korupsi.

B. Saran

1. Kebijakan aturan hukum pidana khususnya mengenai formulasi tindak pidana korupsi saat ini, memiliki sejumlah kelemahan yang mendasar, sehingga berpengaruh pada tingkat efektivitas terhadap pelaksanaan pemberantasan tindak pidana korupsi, karena kelemahan dalam tahap formulasi (in abstracto) merupakan kelemahan strategis bagi tahap berikutnya yaitu tahap aplikasi dan eksekusi (in concret).

2. kebijakan hukum pidana dalam hal tindak pidana korupsi yang berlaku saat ini, tindak mencantumkan kualifikasi delik apakah sebagai "pelanggaran" atau "kejahatan".

3. Diharapkan pemerintah dalam hal ini Eksekutif dan Legislatif lebih serius dalam Pemberantasan Tindak Pidana Korupsi salah satunya dengan segera mewujudkan Pembentukan KPK di daerah.

Copyright @ $\odot$ 2015, LITIGASI, p-ISSN: 0853-7100; e-ISSN: 2442-2274 


\section{DAFTAR PUSTAKA}

Andi Hamzah. 2012. Pemberantasan Korupsi Melalui Hukum Pidana Nasional dan Internasional. Jakarta: Rajawali Pers.

Deni Setiawan. 2008. KPK, Pemburu Koruptor; Kiprah Komisi Pemberantasan Korupsi dalam Memberangus Korupsi. Yogyakarta: Pustaka Timur.

Ermansyah Djaja. 2010. Memberantas Korupsi Bersama KPK. Jakarta: Penerbit Sinar Gerafika.

Hibnu Nugroho. 2012. Integralisasi Penyidikan Tindak Pidana Korupsi di Indonesia. Jakarta: Media Prima Aksara.

Jimly Asshiddiqie. 2006. Pengantar IImu Hukum Tata Negara. Jilid II, cet. 1. Jakarta: Konstitusi Press.

Komisi Pemberantasan Korupsi. 2012. Laporan Tahunan (LAPTAH) KPK, Jakarta: KPK.

Marwan Effendi. 2013. Korupsi dan Strategi Nasional Pencegahan Serta Pemberantasannya, Jakarta: Referensi.

Marwan Effendy. 2005. Kekuasaan Kejaksaan RI (Posisi dan Fungsinya dari Prespektif Hukum). Jakarta: PT. Gramedia.

Marwan Effendy. 2010. Korupsi dan Pencegahan. Jakarta: Timpani Publishing.

Mahmuddin Muslim. 2004. Jalan Panjang menuju KPTPK. Jakarta: Gerak.

O 'Block L. Robert. 1981. Secure and crime Prevention. CV Mosby Company. St Louis.

Syaiful Ahmad Dinar. 2012. KPK dan Korupsi (Dalam Studi Kasus), Jakarta: Cintya Press.

Sumali. 2003. Reduksi Kekuasaan Eksekutif di Bidang Peraturan Pengganti UndangUndang (PERPU). Malang: UMM Pres.

Yopie Morya Immanuel Patiro. 2012. Diskresi Pejabat Publik dan Tindak Pidana Korupsi. Bandung: Keni Media. 
Available online at: http://ejournal.unpas.ac.id/index.php/litigasi

Litigasi, Vol. 16(1), 2015, 2805-2834

DOI: http://dx.doi.org/10.23969/litigasi.v16i1.54

\section{MAKALAH}

Edward Omar Sharif Hiariej. 2012. Pembuktian Terbalik Dalam Pengembalian Aset Kejahatan Korupsi. Pidato Pengukuhan Jabatan Guru Besar. pada Fakultas Hukum Universitas Gadjah Mada. tanggal 30 Januari 2012. Yogyakarta.

Romli Atmasasmita. Perspektif Pengadilan Korupsi di Indonesia. Makalah disampaikan dalam seminar tentang Pembentukan Pengadilan Korupsi. yang diselenggarakan oleh KHN dan BPHN. Jakarta. 30 Juli 2002.

Romli Atamasasmita. Landasan Filosofi Pemberantasan Korupsi di Indonesia. makalah disampaikan dalam seminar korupsi. yang diselenggarakan oleh Fakultas Hukum Universitas Trisakti. Jakarta. 05 Agustus 1999.

Saldi Isra. Makalah, Peran Perguruan Tinggi dalam Pemberantasan Korupsi, disampaikan dalam Seminar Sehari "Penanggulangan Tindak Pidana Korupsi Melalui Pendidikan Tinggi Hukum, dan Launching Pembukaan Program Kekhususan Anti-korupsi", diadakan oleh Fakultas Hukum Universitas Tamansiswa-Padang, di Hotel Inna Muara, Padang, 14 Maret 2009.

\section{WEBSITE}

http://www.republika.co.id/berita/internasional/global/13/07/09/mpndd6-karenakorupsi-cina-hukum-mati-mantan-menteri-kereta-api. diakses tanggal 5 September 2013.

http://www.kpk.go.id/id/tentang-kpk/struktur-organisasi/deputi-pencegahan. Diakses tanggal 3 Juli 2013.

Copyright $\odot$ 2015, LITIGASI, p-ISSN: 0853-7100; e-ISSN: 2442-2274 